\title{
AKUNTABILITAS KINERJA DINAS PENDIDIKAN KABUPATEN BOLAANG MONGONDOW
}

\author{
Abdul Rahman Dilapanga \\ Prodi Ilmu Administrasi Negara FIS Unima \\ Universitas Negeri Manado \\ Email: abdulrahmandilapanga@unima.ac.id
}

\begin{abstract}
ABSTRAK
Pemerintahan yang bersih merupakan suatu tuntutan reformasi guna mengoptimalkan pencapaian tujuan pembangunan nasional. Salah satu indikator penyelenggaraan pemerintahan yang bersih adalah diberlakukannnya sistem pertanggungjawaban penyelenggaraan tugas-tugas pemerintahan. Penelitian ini bertujuan untuk untuk menggali, menganalisis dan menginterpretasi serta memberikan deskripsi tentang Akuntabilitas Kinerja Dinas Pendidikan Kabupaten Bolaang Mongndow. Metode atau pendekatan yang digunakan dalam penelitian ini adalah pendekatan kualitatif, sesuai dengan rumusan masalah dan tujuan penelitian yang bertujuan untuk mengungkap, menganalisis dan menginterpretasikan data lapangan, oleh karena itu digunakan pendekatan kualitatif. Analisis data yang digunakan adalah analisis model interaktif dari Miles dan Huberman. Berdasarkan hasil penelitian dan pembahasan yang telah diuraikan pada bagian terdahulu, maka dapat ditarik kesimpulan bahwa: Akuntabilitas Kinerja Dinas Pendidikan Kabupaten Bolaang Mongondow telah dipertanggung jawabkkan lewat laporan akuntabilitas kinerja instansi pemerintah (LAKIP) dan telah berhasil melaksanakan 6 (enam) program dan 21 kegiatan baik yang didanai melalui APBD maupun APBN dengan capaian rata-rata 100\%. Program-program tersebut diangkat dari tiga tema utama pembangunan pendidikan yaitu: 1) pemerataan dan perluasan akses pendidikan, 2) peningkatan mutu, relevansi, dan daya saing, dan 3) governance, akuntabilitas dan pencitraan publik. Akuntabilitas Kinerja Dinas Pendidikan tergambar melalui: 1) Capaian Kinerja Perluasan dan Pemerataan Akses Pendidikan, 2). Capaian Kinerja Peningkatan Mutu Relevansi dan Daya Saing, 3). Capaian Kinerja Penguatan Tata Kelola, Akuntabilitas dan Pencitraan Publik, 4). Keluaran Program Untuk Mendukung Perluasan dan Pemerataan Akses Pendidikan, 5). Keluaran Program Untuk Mendukung Peningkatan Mutu, Relevansi dan Daya Saing, 6). Keluaran Program Untuk Mendukung Penguatan Tata Kelola, Akuntabilitas dan Pencitraan Publik.
\end{abstract}

\section{Kata Kunci: Akuntabilitas, Kinerja, Pendidikan}

\section{PENDAHULUAN}

Dinas Pendidikan Kabupaten Bolaang Mongondow sebagai salah unsur atau instansi penyelenggara pemerintahan di daerah, dituntut untuk melaksanakan dan mempertanggungjawabkan tugas pokok dan fungsinya yang telah diatur dalam Peraturan Daerah No: 02 Tahun 2009 tentang Organisasi dan Tata Kerja Dinas Pendidikan Kabupaten Bolaang Mongondow.

Akuntabilitas adalah kewajiban untuk menyampaikan pertanggungjawaban atau untuk menjawab dan menerangkan kinerja dan tindakan seseorang/badan hukum/pimpinan kolektif atau suatu organisasi kepada pihak yang memiliki hak atau kewenangan untuk meminta keterangan atau pertanggungjawaban. Sedangkan kinerja instansi pemerintah adalah gambaran mengenai tingkat pencpaian sasaran ataupun tujuan instansi pemerintah sebagai penjabaran dari visi, misi dan strategi instansi pemerintah yang mengindikasikan tingkat keberhasilan dan kegagalan pelaksanaan kegiatan-kegiatan sesuai dengan program dan kebijakan yang ditetapkan. 
Akuntabilitas kinerja instansi pemerintah adalah perwujudan kewajiban suatu instansi pemerintah untuk mempertanggungjawabkan keberhasilan dan kegagalan pelaksanaan misi organisasi dalam mencapai sasaran dan tujuan yang telah ditetapkan melalui sistem pertanggungjawaban secara periodik.

Permasalahannya adalah apakah semua instansi pemerintah di daerah telah mampu merealisasikan visi, misi dan tujuan secara efektif dan efisien? Jika berhasil, kondisi apa saja yang mendukung? Sebaliknya jika mengalami kegagalan, apa yang menjadi penyebabnya? Apakah keberhasilan dan kegagallan dipertanggungjawabkan kepada pemerintah, pimpinan bahkan kepada masyarakat?

Berdasarkan latar belakang masalah yang telah diuraikan di atas, maka penelitian ini dituangkan dalam judul: Akuntabilitas Kinerja Dinas Pendidikan Kabupaten Bolaang Mongondow.

\section{METODE}

Metode atau pendekatan yang digunakan dalam penelitian ini adalah pendekatan kualitatif, sesuai dengan rumusan masalah dan tujuan penelitian yang bertujuan untuk mengungkap, menganalisis dan menginterpretasikan data lapangan, oleh karena itu digunakan pendekatan kualitatif. Penelitian ini memfokuskan pada proses deskripsi dan pemberian makna atas berbagai faktor yang berhubungan dengan akuntabilitas kinerja Dinas Pendidikan Kabupaten Bolaang Mongondow, oleh karena itu penelitian ini menggunakan pendekatan kualitatif. Fokus dalam penelitian kualitatif berkaitan erat dengan masalah yang dirumuskan dan dijadikan acuan dalam penentuan fokus penelitian. Dalam penelitian ini focus utama adalah "Akuntabilitas Kinerja Dinas Pendidikan”

Dengan mengacu pada fokus utama tersebut di atas, maka fokus penelitian teraebut selanjutnya dijabarkan dalam dua pertanyaan penelitian berikut: 1. Bagaimanakah akuntabilitas kinerja Dinas Pendidikan Kabupaten Bolaang Mongondow? Penelitian ini mengambil lokasi Dinas Pendidikan Kabupaten Bolaang Mongondow Provinsi Sulawesi Utara.
Dalam penelitian naturalistik yang dijadikan sampel hanyalah sumber yang dapat memberikan informasi. Sampel dapat berupa hal, peristiwa, manusia, situasi yang diobservasi (Nasution, 1988:32). Selanjutnya Lofland and Lofland, dalam Moleong mengemukakan "sumber data utama dalam penelitian kualitatif ialah kata-kata, dan tindakan selebihnya adalah data tambahan seperti dokumen dan lain-lain”. Sesuai dengan masalah dan fokus dalam penelitian ini, maka sumber data adalah: Key informan, informan awal atau kunci dalam penelitian ini dipilih secara purposif (Stratified Purposive Sampling). Hal ini dilakukan untuk memilih informan yang benar-benar relevan dan benar-benar memahami permasalahan yang diteliti. Sedangkan informan selanjutnya diminta kepada informan awal untuk menunjuk orang lain yang banar-benar dapat memberikan informasi dan kemudian informan ini diminta pula untuk menunjuk informan lain dan seterusnya. Cara ini lazim disebut "snowball sampling" yang dilakukan secara berurutan atau serial. Dalam penelitian ini yang dipandang sebagai informan awal atau key informan adalah Kepala Dinas Pendidikan Kabupaten Bolaang Mongondow.

Dalam penelitian kualitatif, instrument utama adalah peneliti sendiri. Nasution (1988:34) mengemukakan "pada awal penelitian penelitilah alat satu-satunya". Untuk memudahkan dalam pengumpulan data, maka peneliti menggunakan alat bantu berupa pedoman wawancara, field notes, tape recorder, camera foto dan sebagainya.

Teknik pengumpulan data:Wawancara mendalam (In-Depth Interview), teknik ini digunakan untuk menjaring data yang berhubungan dengan : akuntabilitas kinerja Dinas Pendidikan. Observasi, teknik ini digunakan untuk mengamati kondisi sosial terutama interaksi dan kerja sama antar aparatur Dinas Pendidikan. Dokumentasi, teknik ini digunakan untuk menghimpun berbagai informasi tertulis yang berhubungan akuntabilitas kinerja Dinas Pendidikan. Dalam penelitian kualitatif, proses pengumpulan data bergerak dari lapangan empiris dalam upaya membangun teori dari data. Proses 
pengumpulan data dalam penelitian ini dilakukan sepanjang bulan Agustus sampai dengan Oktober 2015, yang meliputi tiga tahapan yaitu: a) Proses Memasuki Lokasi Penelitian (Getting In). Sebelum memasuki lokasi penelitian terlebih dahulu dilakukan persiapan berupa penyiapan pedoman wawancara, surat ijin penelitian dan alat-alat bantu lainnya. Selanjutnya ketika memasuki lokasi penelitian, peneliti melapor dengan menunjukkan surat ijin penelitian sekaligus memohon ijin untuk melakukan penelitian. b). Ketika Berada di Lokasi Penelitian (Getting Along), ketika dan selama berada di lokasi penelitian, maka sebagai peneliti berupaya memperkenalkan diri, mambaur dan menjalin hubungan yang baik dengan semua pihak di lokasi penelitian,sehingga terjalin hubungan yang harmonis dengan mereka. Mencari informasi/data yang lengkap dan berupaya menangkap makna intisari dari berbagai informasi dan pengamatan yang diperoleh.c). Mengumpulkan Data (Logging the data), selama proses pengumpulan data peneliti telah berupaya mendengar, mengamati serta mencatat semua hal yang didengar dan dilihat, selanjutnya dikategorikan menurut pola, tema dan fokus penelitian. Membuat catatan lapangan, memo (aganda penelitian selanjutnya) dan member check, sertra mengembangkan dan menelusuri kasus-kasus negatif. Pada tahap ini peneliti menggunakan tiga teknik pengumpulan data yaitu wawancara, observasi dan dokumentasi.

Dalam penelitian kualitatif, analisis data dilakukan sejak awal dan sepenjang proses penelitian berlangsung. Analisis data digunakan model analisis interaktif dari Miles dan Huberman (1992:15-20) yaitu: Reduksi Data, Penyajian Data dan Verifikasi. Komponenkomponen analisis data model interaktif.

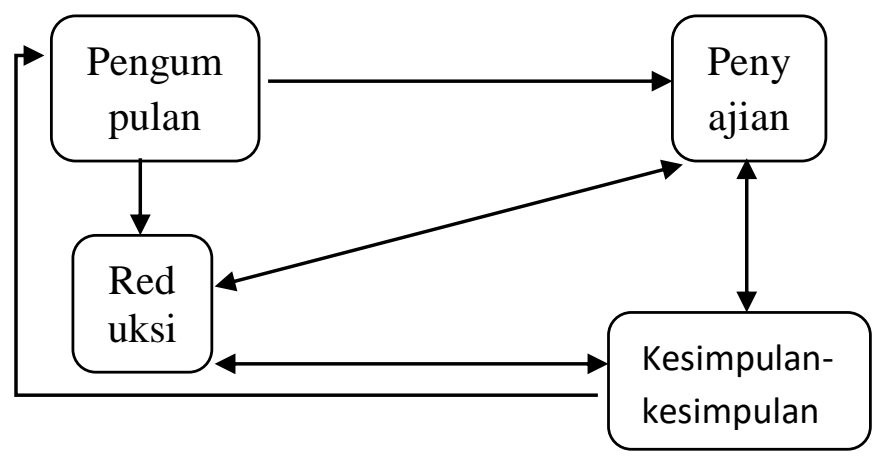

Untuk keabsahan data digunakan empat uji kriteria yang dikemukakan oleh Moleong (1994:173) dan Nasution (1998:105) yaitu: a) derajat kepercayaan, b) keteralihan, c) ketergantungan, d) kepastian.

\section{HASIL PENELITIAN DAN PEMBAHASAN}

Berdasarkan hasil pelaksanaan evaluasi pengukuran kinerja Dinas Penidikan Kabupaten Bolaang Mongondow, selang tahun 2014 yang telah dipaparkan pada hasil penelitian di atas yang mencakup enam kegiatan dan keluaran, maka Dinas Pendidikan Kabupaten Bolaang Mongondow telah berhasil melaksanakan 6 (enam) program dan 21 kegiatan baik yang didanai melalui APBD maupun APBN dengan capaian rata-rata $100 \%$.

Capaian pelaksanaan kegiatan tersebut menjukkan akuntabilitas kinerja Dinas Pendidikan Kabupaten Bolaang Mongondow, sangat baik dan telah berjalan sesuai rencana dan sasaran strategis pembangunan pendidikan yang lebih realistis. Sebab rencana strategik yang disusun telah menggunakan pendekatan sektor secara keseluruhan dalam rangka mewujudkan integrasi dan harmonisasi antar program. Keterkaitan antar program prmbangunan pendidikan memang sangat diperlukan agar tercapai efisiensi dan produktivitas sektor secara optimal.

Rencana strategis Dinas Pendidikan sebagaimana diuraikan pada hasil penelitian bertolak dari tiga tema utama pembangunan pendidikan yaitu: 1) pemerataan dan perluasan akses pendidikan, 2) peningkatan mutu, relevansi, dan daya saing, dan 3) governance, akuntabilitas dan pencitraan publik.

Pemerataan dan perluasan akses pendidikan diarahkan pada upaya memperluas daya tamping satuan pendidikan sesuai dengan prioritas nasional, serta memberikan kesempatan yang sama bagi semua peserta didik dari berbagai golongan masyarakat yang berbeda baik secara sosial ekonomi, gender, lokasi tempat tinggal dan tingkat kemampuan intellectual serta kondisi fisik. Kebijakan ini ditujukan untuk meningkatkan kapasitas penduduk Kabupaten Bolaang Mongondow untuk dapat memperoleh kesempatan belajar sepanjang hayat 
Penuntasan Wajar Dikdas 9 Tahun juga telah menambah lulusan SMP/MTs dari tahun ke tahun sebagaimana dipaparkan pada tabel 4.2 di atas, dengan sendirinya juga mendorong perluasan akses pendidikan pada jenjang menengah, sehingga lulusan SMP/MTs dapat pula menikmati pendidikan menengah (SMA/SMK dan MA).

Kebijakan peningkatan mutu pendidikan di arahkan pada pencapaian mutu pendidikan yang semakin meningkat sesuai Standar Nasional Pendidikan (SNP) yang meliputi berbagai komponen yang terkait dengan mutu pendidikan yang mencakup standar isi, standar proses, standar kompetensi lulusan, standar pendidik dan tenaga kependidikan, standar sarana dan prasarana, standar pengelolaan, standar pembiayaan, dan standar penilaian pendidikan.

Peningkatan mutu dan relevansi pendidikan diukur dari pencapaian kecakapan akademik dan non akademik yang lebih tinggi sehingga memungkinkan lulusan dapat beradaptasi dan proaktif dalam menghadapi tantangan dan perubahan masyarakat dalam berbagai bidang kehidupan.

Selanjutnya hasil penelitian yang berhubungan dengan tema ketiga yaitu; governance, akuntabilitas dan pencitraan publik, maka Dinas Pendidikan Kabupaten Bolaang Mongondow, telah menetapkan dan melaksanakan kebijakan governance dan akuntabilitas yang meliputi pembiayaan berbasis masyarakat,, dan manajemen berbasis sekolah (MBS). Di samping itu peran serta masyarakat dalam perencanaan, pengelolaan, dan pengwasan kinerja pendidikan ditingkatkan melalui peran komite sekolah pada satuan pendidikan dan dewan pendidikan.

Upaya-upaya dan langkah-langka tersebut dilakukan dan ditujukan untuk mewujudkan pemerintahan yang bersih dan bebas KKN. Di samping itu juga ditujukan pada pemberian pelayanan yang lebih bermutu, efektif dan efisien sesuai kebutuhan masyarakat. Pemerintahan yang bersih dan bebas KKN hanya dapat diwujudkan melalui internalisasi etos kerja serta disiplin kerja yang tinggi sebagai bentuk

akuntabilitas aparatur Negara serta perwujudan profesionalitas aparatur. Untuk itu aparatur dalam lingkungan Dinas Pendidikan Kabupaten Bolaang Mongondow perlu meningkatkan kinerjanya dalam mewujudkan pelayanan yang bermutu, merata, dan adil dalam suatu tata pemerintahan yang sehat dan akuntabel.

\section{KESIMPULAN}

Berdasarkan hasil analisis data dan pemabahasan hasil penelitian yang telah diuraikan di atas, maka dapat disimpulkan bahwa; Akuntabilitas Kinerja Dinas Pendidikan Kabupaten Bolaang Mongondow telah dipertanggung jawabkkan lewat laporan akuntabilitas kinerja instansi pemerintah (LAKIP) dan telah berhasil melaksanakan 6 (enam) program dan 21 kegiatan baik yang didanai melalui APBD maupun APBN dengan capaian rata-rata $100 \%$. Program-program tersebut diangkat dari tiga tema utama pembangunan pendidikan yaitu: 1) pemerataan dan perluasan akses pendidikan, 2) peningkatan mutu, relevansi, dan daya saing, dan 3) governance, akuntabilitas dan pencitraan publik.

Akuntabilitas Kinerja Dinas Pendidikan tergambar melalui: 1) Capaian Kinerja Perluasan dan Pemerataan Akses Pendidikan, 2). Capaian Kinerja Peningkatan Mutu Relevansi dan Daya Saing, 3). Capaian Kinerja Penguatan Tata Kelola, Akuntabilitas dan Pencitraan Publik, 4). Keluaran Program Untuk Mendukung Perluasan dan Pemerataan Akses Pendidikan, 5). Keluaran Program Untuk Mendukung Peningkatan Mutu, Relevansi dan Daya Saing, 6). Keluaran Program Untuk Mendukung Penguatan Tata Kelola, Akuntabilitas dan Pencitraan Publik. 


\section{DAFTAR PUSTAKA}

Badan Pusat Statistik, 2014, Bolaang Mongondow Dalam Angka, BPS Kabupaten Bolaang Mongondow Dinas Pendidikan Kabupaten Bolaang Mongondow, 2014 Laporan Akuntabilitas Kinerja Instansi Pemerintah (LAKIP), Diknas Kab. Bolaang Mongondow.

Dwiyanto, Agus, 1995, Penilaian Kinerja Organisasi Pelayanan Publik (Seminar Kinerja Organisasi

Sektor Publik, Kebijakan dan Penerapannya), Jurusan Administrasi Negara, FISIP UGM Yogyakarta.

--------, 2008, Mewujudkan Good Governance Melalui Pelayanan Publik,_University Press, Yogyakarta.

LAN dan BPKP, 2003, Pedoman dan Modul Akuntabilitas Kinerja Instansi Pemerintah (AKIP), LAN, Jakarta.

Mahsun, Mohamad, 2009, Pengukuran Kinerja Sektor Publik, BPFE. Yogyakarta.

Miles, Huberman, 1992, Analisis Data Kualitatif, (Terjemahan Tjetjep Rohadi), UI Press, Jakarta.

Moleong, Lexi, 1994, Metode Penelitian Kualitatif, Remaja Rosdakkarya, Bandung.

Nasution, S, 1988, Penelitian Kualitatif Naturalistik Inquiry, Tarsito, Bandung.

Santosa, Pandji, 2009, Administrasi Publik, Teori dan Aplikasi Good Governance, PT Refika Aditama, Bandung.

Sedarmayanti, 2013, Reformasi Administrasi Publik, Reformasi Birokrasi dan Kepemimpinan Masa Depan (Mewujudkan Pelayanan Prima dan Kepemerintahan yang Baik), Refika Aditama, Bandung.

-,2014, Restrukturisasi Dan Pemberdayaan Organisasi, PT Refika Aditama, Bandung.

Sinambela, Lijan Poltak, 2011, Reformasi Pelayanan Publik, Bumi Aksara, Jakarta. 